\title{
SELL wt Allele
}

National Cancer Institute

\section{Source}

National Cancer Institute. SELL wt Allele. NCI Thesaurus. Code C51189.

Human SELL wild-type allele is located within 1q23-q25 and is approximately $21 \mathrm{~kb}$ in length. This allele, which encodes L-selectin protein, is involved in the regulation of neutrophil adhesion to endothelium at sites of inflammation. 